\title{
THE ALIMENTARY CANAL OF FLATA AND OTHER HOMOPTERA.
}

\author{
By J. C. Kershaw, \\ Trinidad, B. W. I.
}

In many of the Delphacidæ and Fulgoridæ there is a large foodreservoir or crop whose anterior end penetrates the thorax and often enters the head-in Pyrops and Dictyophorodelphax reaching to the tip of the greatly produced epicranium. In the present subject, Siphanta acuta Walker, a Flatid or Pocillopterid the reservoir is very large and, from its junction with the osophagus just within the abdomen, extends anteriorly above the œesophagus through the thorax and practically fills the epicranium above the brain. It also extends posteriorly - beneath the heart and above the rest of the internal organs - almost to the tip of the abdomen; when inflated it also spreads out laterally over the other organs, and expands into every available space in the body-cavity, and is then very irregular in contour, becoming much more shapely when contracted or when dissected out of the insect.

In the thoracic portion the reservoir possesses four rather large but often irregularly shaped latero-ventral cæca or pouches (fig. 3, ca), two on either side, which sometimes extend downwards into the coxæ in a manner analogous to the mesenteric cæca of spiders. Anterior to these cæca are two much smaller latero-ventral cæca, one on either side; to the end of each cæcum a slender and rather long muscle is attached, the other end of the muscle attaching to the lateral posterior margin of either side of the prothorax. Occasionally the other cæca also possess slender muscles which attach them to the body-walls, thus serving to anchor the reservoir, but still allowing it plenty of freedom to expand and contract. The reservoir, although tracheæ ramify over it as they do over the rest of the mesenteron, is not moored by them to the body-walls. The tracheæ are not shown in the figures.

This reservoir is an extension of the mesenteron and not of the osophagus, as appears by the character of its epithelium and its development in the embryo. In the latter (figs. 1 and 2) 
the mesenteron, including the reservoir, is completed very shortly - one or two days-before the nymph hatches out; but the oesophagus and salivary glands, the rectum and malpighian tubes are complete several days earlier. The chitinous intima of the œsophagus and rectum is already secreted, though as yet in a plastic condition, at the stage shown in figure 2. The dorsal wall of the midgut and the anterior part of the reservoir are the last portions of the mesenteron to close up and complete. The midgut appears to proliferate from a small mass of cells at the inner ends of the osophagus and rectum respectively: it appears, therefore, to be of ectodermal origin. The basement-membrane of the mesenteric epithelium is more or less chitinous and apparently secreted by the epithelium itself. The peritoneal membrane is largely developed in this insect (and many other Homoptera, and more or less envelops the whole alimentary canal and its appendages, and appears to be only deficient over the anterior part of the œsophagus, a small posterior portion of the rectum and the long loop (fig. 3, part outside line indicating peritoneal membrane) of the midgut; but it is probable that it is merely exceedingly delicate over this area, and, therefore, practically invisible. In figures 3 and 4, however, the peritoneal membrane is only shown over those parts where it is a really thick tissue, and thus in figure 4a it appears to leave the osophagus anteriorly and continue only on the reservoir. The posterior part of the œesophagus, the anterior part of the rectum, part of the midgut and reservoir and the proximal portions of the malpighian tubes lie alongside one another in close contact, and are also twisted around each other. The whole tangle is closely invested by the peritoneal membrane; in figure 3 the parts are not shown twisted, in order to keep the figure clear. There is a constriction (fig. 4 frv.) around the reservoir, just in front of the œesophageal valve, provided with extra annular muscles; this occasionally shows as a slight invagination (similar to the osophageal valve), but in any case it forms a valve for the reservoir, to admit or prevent the passage of food therein.

Berlese supposes (in apparently similar cases, of Coccidæ) that by this unusual arrangement of the alimentary canal and its appendages, osmosis of the innutritious watery part of the food and the excess of sugar therein, may take place through the various 
parts in contact with the delicate walls of the organs directly into the rectum or posterior part of the gut; thus avoiding passage through the long and tortuous midgut, but leaving the more nourishing matters to take the ordinary course through the whole canal. This would, in fact, be supplementing the action of the peritrophic membrane, whose chief function seems to be that of separating the useless from the useful portions of the food-or rather, retaining the indigestible matter within the membrane till its evacuation from the anus. Certainly the twisted loops of the gut are in intimate contact and their tissues even in part grown together or fused: from which cause this part of the gut is difficult to disentangle without injury. Feeding the insects on colored liquids tends to confirm this theory, since the contents of the long loop of the midgut are very faintly if at all tinted, whilst the rectum is heavily colored.

The epithelium of the reservoir (fig. 4) is formed chiefly by low but very irregular cells, which appear to be in a constant state of degeneration and renewal. In sections from a long series of reservoirs of Siphanta during almost every month of the year, there was not one with a moderately perfect epithelium; but one reservoir of Perkinsiella was once obtained in very good (apparently resting) condition, out of a long series. The young cells have a single nucleus, but the older ones are mostly bi-nucleated, though very often a cell will have but one enormous nucleus. The epithelium of the cæca is similar but usually in rather more perfect condition, and seems to be constantly renewed by young cells at the bottom or end of the cæca. The cells of the reservoir are in one place or another apparently always secreting; after a time the nuclei become much larger and irregular in shape and the cells become detached from the basement-membrane, or are thrust from it by the new cells. When several contiguous cells become detached they seem to carry with them part of the intercellular cement or membrane, which shows in sections as an irregular reticulum; or it may be the cell-walls persisting longer than the contents. The cast-off cells generally assume a more or less globular form (probably on escaping from the lateral pressure of adjoining cells of the epithelium) and rapidly disintegrate, the nuclei becoming less and less distinct; finally the cells appear to become a granular and somewhat viscid fluid (probably the granules rep- 
resent enzymes) and afterwards the viscid matter seems to take part in the formation of the so-called peritrophic membrane. The young nuclei take hæmatoxylin strongly; the secreting upper portion of the cells and the cast-off disintegrating cells tend to stain lightly with acid fuchsin or congo red or picric acid; or else they refuse to stain at all.

The peritrophic membrane seems to be secreted also by the epithelium all along the midgut, although the nuclei of the cells of the osophageal valve appear different from those of adjoining cells, as if they might be special cells secreting the whole membrane; as concluded by Miall and Hammond in the case of Chironomus . 'But this does not seem probable with regard to Siphanta, because certain cells along the whole midgut epithelium can be plainly observed secreting, some of the globules of secretion adhering to and spreading over the outermost layer of the peritrophic membrane. This latter extends from the anterior end of the reservoir through the whole canal to the anus, where it appears to pass out with the rest of the excrement, in a granular or disintegrated condition. The peritrophic membrane is seen in transverse sections (fig. $4 \mathrm{~B}, \mathrm{pm}$ ) to be composed very often along some parts of its length of more than one membrane or parts of several non-synchronous secretions, one within anotker and more or less concentric. It is not very evident how the peritrophic membrane itself can protect the mesenteric epithelium -as it is said to do-by keeping particles of food etc. from contact therewith, since the membrane is very irregular in contour and, when shrunken, comparatively rough, with occasional parts of cell-walls and other matters in its wall not completely digested or dissolved; it is also more or less chitinous. It would appear, rather, that the epithelium of the mesenteron is protected from both food-particles and peritrophic membrane by the layer of viscid fluid mentioned above, which is between the epithelium and the membrane, and which afterwards - in part at leastseems to compose the said membrane. This fluid would tend to keep the latter with its contents fairly in the center of the alimentary canal, even when rounding the numerous sharp bends of the gut. But it may be that only the older internal membranes

1 The Harlequin fly, Miall and Hammond, 1900. 
move endways or disintegrate, passing through the recentlysecreted membranes to the rectum, the recent membranes merely being pushed inwards (towards the centre of the canal) by yet more recent membranes.

The reservoir epithelium, tested by litmus in many specimens, invariably gave a very decidedly acid reaction; but the juices of leaves and young stems of Eucalyptus robusta, on which the Flatids were feeding, is very acid and immediately reddens blue litmus paper. Probably, therefore, the acidity of the reservoir is due to the food. From the results of feeding several Siphanta on rods of pith soaking in red or acid azolitmin, the secretions of the whole alimentary canal appear to be very slightly alkaline, since the contents tended to become more bluish: the epithelium itself does not stain, or not perceptibly. In one specimen fed as above for three days, the contents of the whole gut were faintly red, except the rectum which was strongly blue, with no trace of purple. The chief function of the reservoir seems, on account of its secretive activity, to be digestive. It may also in some way aid in getting rid of the waxy matters which are so abundantly excreted by these insects. It also collects a quantity of air, separated from the food imbibed; there is always some air, often (especially just after the moult to adult) a very large amount. In the many specimens examined there was always some liquid in the reservoir, and sometimes it was nearly full; the contents were well shown by feeding the insects on Sonchus plants growing in water deeply tinged with fuchsin. The liquid food in the alimentary canal always appears to contain a percentage of waxy matter, as does the excrement, although the greater part of the wax in the latter is due to wax-dust from the anal segment waxglands, which forms a powdery film over the globule of excrement immediately on its evacuation from the anus.

Probably some sugar, and fat in the form of oil, is imbibed with the food and directly assimilated; passing outwards by osmosis through the peritrophic membrane and being absorbed by the cells of the posterior part of the alimentary canal. The digestive matters of the enzymes could also pass inwards through the membrane and convert starch into sugar and peptonise proteids; the products of digestion could then also pass outwards through the membrane, ready for absorption by the cells of the epithelium. 
It would seem possible that the diastase of the plant may be imbibed with the rest of the juices, and assist the action of the digestive secretions of the insect. It does not seem probable that the reservoir is a mere store-vessel only, to be drawn upon intermittently. It may perhaps be so spacious in order to give increased area for the digestion and absorption of a comparatively innutritious food, ${ }^{1}$ so that it may be rapidly passed on and fresh supplies taken in. On the other hand many Homoptera feeding in like manner on the same plants have no reservoir, though perhaps in these the area of the gut is increased in other directions.

In the nymph just hatched the reservoir does not always enter the head, but soon afterwards it does so, and is completely formed at the time the nymph hatches out. In the head the reservoir lies practically free, but is slightly attached by connective tissue to the front of the head-capsule.

In the nymphs, at each successive moult, there is an almost total and sudden degeneration and disappearance of the epithelium of the alimentary canal, very little remaining but the musculature and peritoneal membrane. The epithelium is then very quickly regenerated.

The muscles of the osophagus consist of two layers of stout annular fibres crossing each other almost at a right angle (fig. 4). The nuclei of the osophageal valve are larger than those of the rest of the œsophagus, and rounder than those of the mesenteric epithelium. They probably secrete more actively than the rest of the osophageal cells, since the six chitinous folds of the intima are much thicker at the valve, forming six cushions or pads at its summit. There seem to be no special glandular cells in the œsophagus, but the salivary-glands and reservoirs in this insect are very voluminous. They give a decidedly alkaline reaction when tested with litmus. Their secretion would probably convert

\footnotetext{
I That it is a somewhat innutritious food compared with that of carnivorous insects may be inferred from the time the insect spends in feeding, and the large amount of excrement continually voided, compared with a carnivorous insect. And besides the fæces must be included as excrement the large quantity of waxy substances excreted from various parts of the body. For although the wax of Homoptera may have become useful in certain ways, such as a covering for their eggs when laid, etc., yet originally it can have had no such use, but was a waste product to be gotten rid of. Yet the phloem of plants contains in the sieve-tubes much proteid matter in the form of a nitrogenous slime, which must be sucked up by the insect along with the rest of its liquid food. Perhaps the Homoptera require such large quantities of food because it is not in a very concentrated form.
} 
much of the starch into sugar before its entrance to the mesenteron, since the secretion is poured out on the hypopharynx, where it mingles with the food, and has then to traverse the pharynx and long oesophagus before entering the mesenteron. The oesophageal valve does not usually lie exactly beneath the reservoir as shown for the sake of clearness in figure 3, but both œsophagus and reservoir twist slightly near the valve, $i$. e., as soon as they leave the thorax with its mass of muscles and enter the abdomen and have more space, so that the valve and reservoir generally lie somewhat on the right-hand side.

The mesenteric musculature (fig.4) consists of an inner transverse and an outer longitudinal layer of rather slender fibres. In the rectum this disposition of the muscles is reversed.

The four malpighian tubes (fig. 3) for the greater part of their length are plain, rather large diameter tubes, but the short distal portion is of smaller diameter and lobulate, the cells of one side alternating with those of the other. The nuclei of the main portion are more or less globular, those of the distal portion long or oval, but these latter sometimes become very irregular and much branched, probably when actively secreting. This distal part seems to secrete from the blood and excrete into the lumen of the tube a resinous-waxy substance, allied to that of the cuticular wax-glands; it was obtained by boiling several of the distal ends in ether in a small test-tube. The whole tube is at times of a hyaline appearance, of smaller diameter and in color pale yellowish. Generally the main portion is opaque white and often greatly distended for its whole length with urates, calcium oxalate and other waste products, whilst these are not found in the distal portion, which always remains hyaline. The proximal part of the tube, just at its entrance to the gut, somewhat resembles the distal part. The tubes are covered externally by peritoneal membrane, with a few elastic fibres and tracheae; they have a chitinous basement-membrane, apparently secreted by the epithelium which rests upon it; the lumen of the tube is lined by a thick chitinous secretion of the epithelial cells, and has a distinctly striated appearance. When treated with potash and examined under a high power, the intima is seen to be creased or furrowed longitudinally, so that it has the appearance of being formed of six strands fused together spirally-much like a piece of rope. 
At times the epithelium also appears transversely striated, $i$. e., at right angles to the length of the tube; especially in sections or when teased fresh in potash. When the malpighian tubes are swollen with urates, etc., if placed in weak acetic acid the entire contents-urates, intima and epithelium - are quickly evacuated, and the basement and peritoneal-membranes left as an empty shell.

The cells of the epithelium of the tubes seem to disintegrate locally and be replaced by new cells, and frequently (when fully loaded and distended with urates, etc.) the epithelium of long portions of the tubes appears to disintegrate and to fall into the lumen, dissolve and be discharged into the rectum, new cells taking their place. This seems to recur several times during the life of the insect. At all times some of the cells can be seen in sections secreting large globules of matter into the lumen. The distal ends stain much more heavily than the rest of the tube.

The contents of the malpighian tubes give a decided reaction to the murexide test; when the tubes are white and swollen they contain a very large quantity of urates of soda and ammonia in minute roundish granules, appearing to the unaided eye as a whitish sediment; under the microscope they appear white by reflected and pale yellow-brown by transmitted light. By treatment with dilute acetic acid ( 2 per cent.) very many large colorless crystals and bundles of crystals of uric acid ${ }^{1}$ are usually to be seen, which resist the action of hydrochloric acid. Calcium oxalate crystals also occur in numbers, and do not dissolve in water nor in acetic acid, but are entirely dissolved by hydrochloric acid. They may be distinguished microscopically by their form (squarish, with two diagonal lines from corner to corner), and chemically by the decoloring of permanganate of potash added to a solution of the calcium oxalate crystals in sulphuric or hypochloric acid.

Sometimes, on leaving the tubes in water for about twentyfour hours, they are surrounded by a layer of mucilaginous matter which appears to have exuded from the whole of the tubes except the distal ends. Occasionally the tubes are very irregularly swollen here and there into lumps, and are then usually of a bluish hyaline appearance. In this state, which is not common, they

1 And also what look very like hippuric acid crystals. 
seem to contain much waxy matter, and comparatively few urates. But the malpighian tubes require much more study in long series and at all periods from nymph, to adult.

Whilst examining many adults of Siphanta acuta, one specimen was found which had one tube completely and perfectly forked distally, just as in Perkinsiella saccharicida.

The malpighian tubes of the Homoptera mentioned in this paper are not intricately mixed up with the fat-body and other internal organs, nor so much tied and entangled with tracheæ as in most insects. The distal ends nearly always lie very near the extremity of the abdomen. Occasionally the tubes are connected by the tissue of their distal ends, generally in pairs, but their lumina do not communicate.

The tips of the setæ of Siphanta do not appear to penetrate the xylem of vegetation, but it is difficult to kill a specimen so that the setæ are left in the foodplant. The sketch given (fig. 5) was made from a mealybug (Icerya purchasi). Several were feeding close together on a young stem of a leguminous tree, and a piece of this was suddenly plunged into benzene, which kills them quickly. Some of the sections made showed the setæ even more twisted than those in the sketch. When the tips of the setæ encounter any hard obstacle they glance aside till they meet another hard spot, again following the least resistance till they reach the layers of tissue next the cambium. Some of the mealybugs had penetrated the cambium, but none had entered (though one or two had touched) the xylem. This might be expected, since all the matters useful as food to the insect are contained in the tissues external to the xylem: the contents of the latter being mere water with mineral salts in solution.

The tissues of the Eucalyptus trees on which these Flatids were feeding contain a large quantity of oil and resinous-wax. Some of these substances must be imbibed by the insects, and a great deal of wax (more or less resinous) is excreted by them during their nymphal and adult life. This wax is largely secreted and excreted by anal wax-gland areas, but minute wax-glands are scattered over almost all parts of the insect, even on the head and wings. They are very numerous and rather large on the claval area of the tegmina of Siphanta, and they occur on the tip of the epicranium of Pyrops. The Membracidæ also have small 
wax-glands on the tegmina, and in the nymph they are numerous on the pronotal hood. They occur in most positions where "sensory-organs" also occur, and being also little crater-like processes on the cuticle may sometimes be mistaken for the latter organs.

A fairly large quantity of the wax excreted from the various cuticular glands was collected by boiling the cast skins of nymphs with ether in a Soxhlet extractor, and the following data therefrom were kindly given by Mr. S. S. Peck, chemist at this experiment station, ${ }^{2}$ to whom also I am indebted for some tests of the contents of the malpighian tubes given above:

The wax is slightly soluble in alcohol and in ether, easily soluble in benzene. It separates in crystal form. Sp. gr. at $17^{\circ}=.0972$, at $90^{\circ}=.0826$. Melting-point $80^{\circ}-83.5^{\circ}$.

A quantity of leaves and bark from young stems of Eucalyptus was extracted with benzene in the cold, and the liquid then evaporated, when a fairly thick film of resinous-wax was left on the bottom and sides of the vessel. This residuum was green from contained chlorophyll. The wax appeared to be similar in part to that excreted by the malpighian tubes of the insect, and also by the cuticular wax-glands.

The total length of the adult alimentary canal from the beginning of the osophagus to the anus is about $35 \mathrm{~mm}$., when not unduly extended.

Siphanta acuta appears to live about two. months as an adult. One individual fed well on a young growing Eucalyptus tree, and moulted to adult on April 28, dying on July 1. Another specimen was very near these dates, and both apparently died of old age, the bright coloring having become very dull, in some parts whitish, in others yellow-brown. The vivid yellow-green of young adults becomes a glaucous green in older individuals. Although in the early part of the year the eggs of this Flatid hatch in about twenty days, in the fall they hatch in about ten days.

The three tissues of the midgut-basement-membrane, epithelium and intima-seem homologous with the corresponding tissues of the stomodæum, proctodæum and body-walls. The basement-membrane of the epidermis is chitinous, and that of

2 Hawaiian Sugar Planters' Experiment Station. 
the midgut is also chitinous though very thin. Both epithelia are very similar and secrete a more or less chitinous material from the free ends of the cells, though the somewhat chitinous intima is modified from the highly chitinous secretion of the cuticle. Of the two mesodermic tissues the muscular layer invests the inner wall of the body-cavity and also what is really (if the whole gut is of ectodermic origin) the inner wall of the alimentary canal; the intima of the lumen being its outer or external wall; it also invests the appendages of the gut. The peritoneal layer forms in Siphanta an apparently complete investiture of the alimentary canal, though it is in some parts exceedingly thin and barely visible. In the embryo the peritoneal layer seems to originate in close connection with the pericardial and neural septa.

If the midgut is really of ectodermic origin, then that part of the secretion which eventually seems to produce the peritrophic membranes is probably a modification of the secretion which forms the chitinous cuticle. The membranes resist for some time the action of potash: however, the secretion which produces chitin is easily soluble in potash if it is acted upon soon after being secreted and before much exposure to the external air. The secretions of certain colleterial glands also are very soluble in potash when freshly secreted, but soon become almost insoluble, apparently from the action of the external air.

In the Cixiid genus Oliarus, at least in the Hawaiian species (fig. 6), the anterior part of the reservoir extends to the head but does not enter it: makes a sharp bend and returns through the thorax to near the abdomen, lying close alongside the posterior part. In the younger nymphal instars the reservoir is not so long, and has no bend and return portion, but this develops before the final moult to adult. The malpighian tubes are forked distally for a great length, the forked portion being lobulate, the rest smooth and of smaller diameter. They are generally of a pale brown.

In Dictyophorodelphax mirabilis Swezey, an endemic Hawaiian Delphacid (fig. 7), the reservoir enters the headcapsule and continues to the tip of the greatly produced epicranium. The malpighian tubes are forked distally for a moderate length, the forked part being lobulate, the rest smooth. They are of a pale brown.

In Perkinsiella saccharicida Kirk., a Delphacid (fig. 8), the 
reservoir enters the head. The malpighian tubes are forked distally for a considerable length, the forked and about half the single portion being lobulate, the rest smooth. The color varies from pale pink to dark purple-red.

In the family Membracidæ the alimentary canal (fig. 9) differs in arrangement from the foregoing insects. The anterior part of the reservoir only projects slightly into the thorax: posteriorly it extends to near the extremity of the abdomen as a sac of large diameter, though gradually narrowing to the reservoir-valve. The posterior part of the oesophagus, together with portions of the midgut and proximal parts of the malpighian tubes are wound or twisted together, so that it is very difficult to disentangle without injuring them, especially as their tissues where in contact coalesce, and the whole mass or knot is invested by peritoneal membrane. The malpighian tubes are forked, the fork extending to somewhat near their point of origin. They originate as two tubes, each of which afterwards forks and together form the usual four tubes. The proximal single portions are smooth, the rest lobulated. Often the mid-part of the tubes is much swollen for a considerable length by urates, etc., and this portion is then of an opaque white. Otherwise their color is pale brownish or yellowish. The distal ends generally abut on the rectum, into which they usually bulge somewhat. In other cases the distal ends are sometimes united in pairs, but their lumina do not communicate.

Of the family Aleyrodidœ, Aleyrodes, sonchi Kotinsky, a native of the Hawaiian islands (fig. 10), has no reservoir. The osophagus is very long and slender, and the posterior portion of it, together with the anterior part of the hind intestine are twisted around each other for some distance, and apparently enclosed with a peritrophic membrane. The malpighian tubes are two in number and very large; they appear to be always more or less clear or hyaline and colorless. Besides uric acid there appeared to be hippuric acid crystals in the tubes. The junction of the midgut and hind intestine (where the malpighian tubes originate) is right up at the anterior end of the abdomen, near the base of the osophagus, when the gut lies in its natural position in the abdomen. The tegimina and wings of this insect are white from the wax excreted from the numberless tiny glands thereon. 


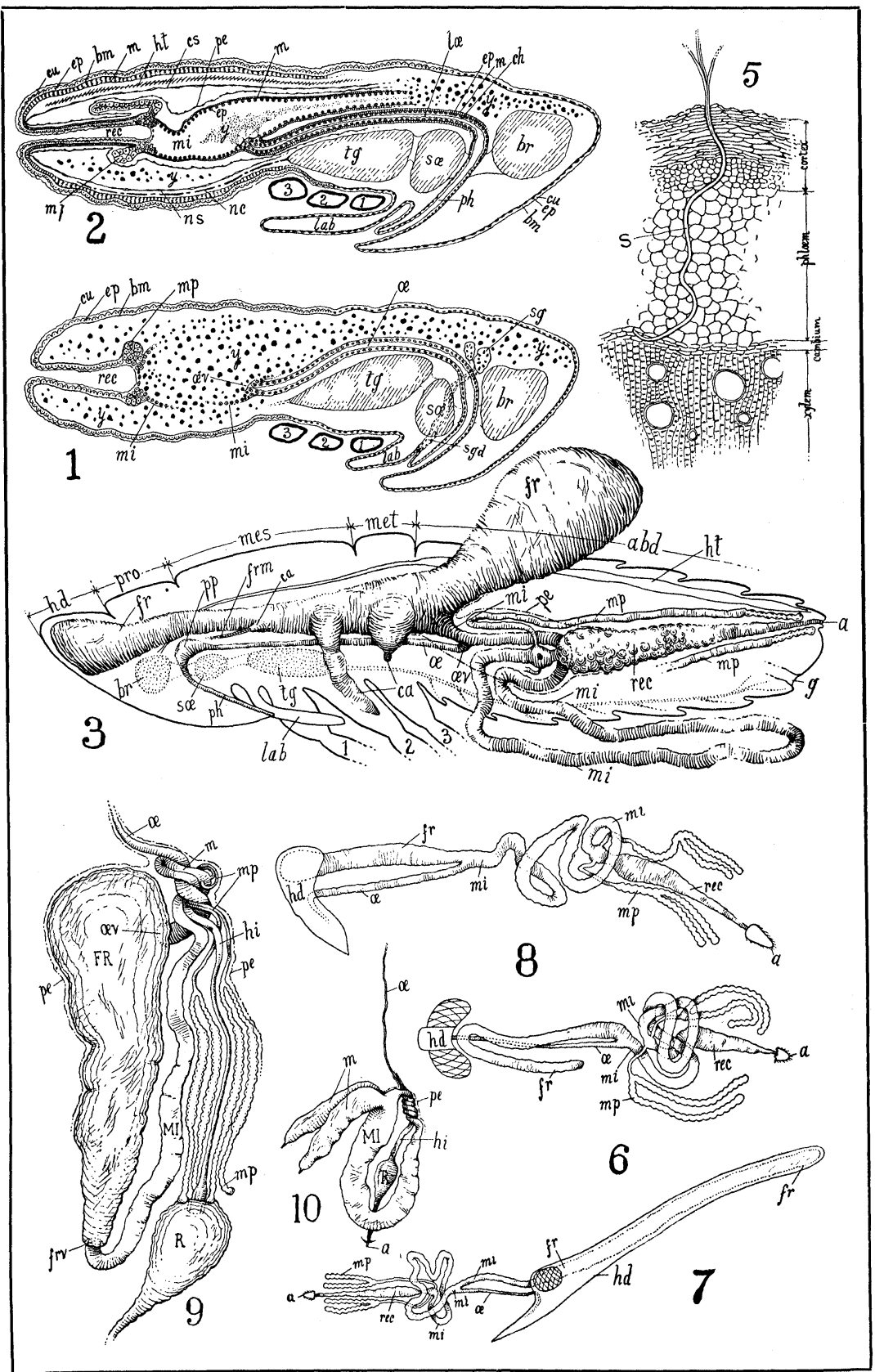

Kershaw-Alimentary Canal of Flata and Other Homoptera. 


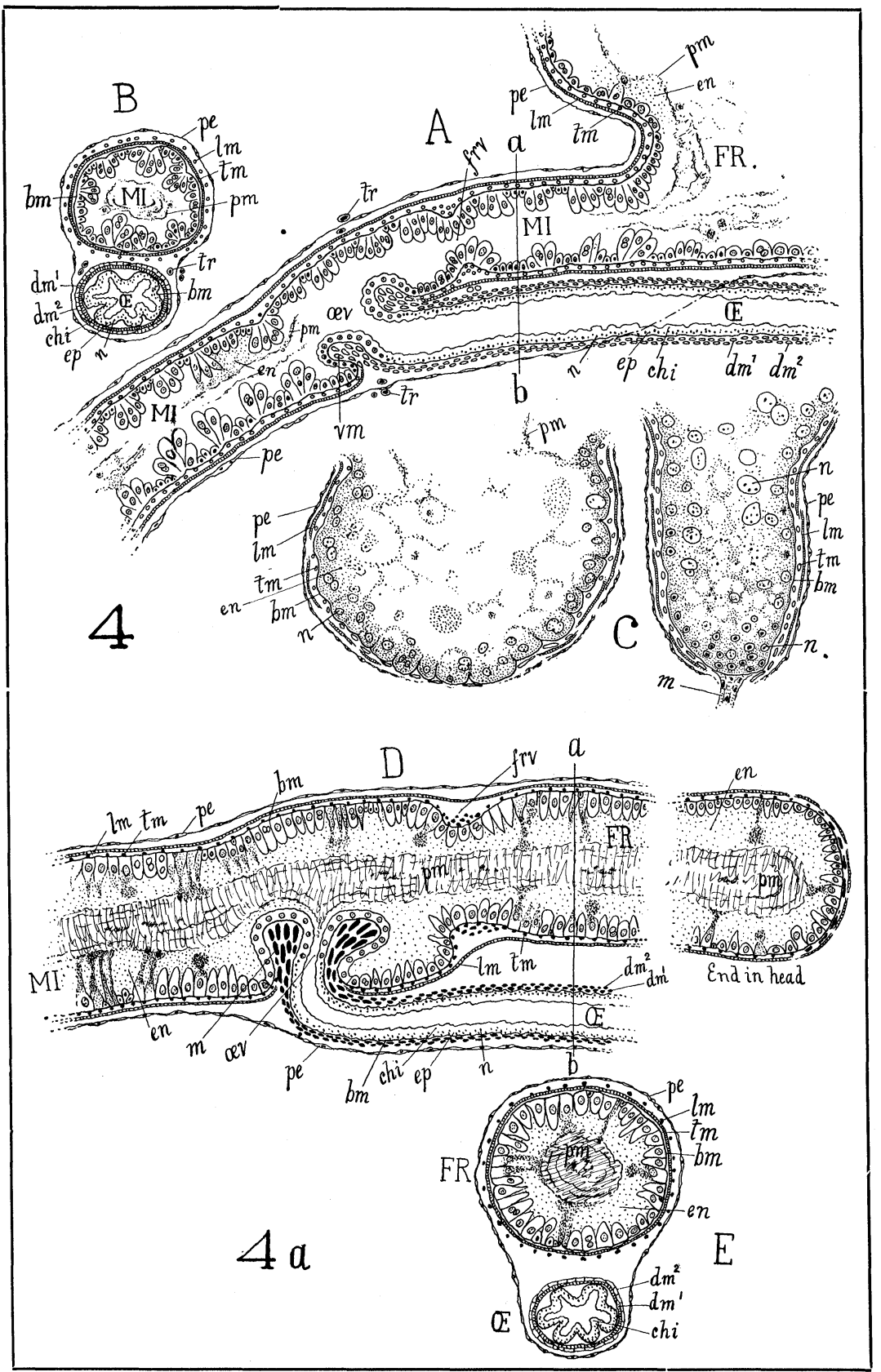

Kershaw-Alimentary Canal of Flata and Other Homoptera. 
In conclusion, I am indebted to Dr. H. Lyon, the pathologist of this experiment station, for much information about the plants on which these insects feed, especially with regard to the nature of the vegetable juices which they imbibe.

\section{EXPLANATION OF FIGURES.}

1. Early embryo of Siphanta acuta. Fam. Flatidæ.

2. Later embryo of the same.

3. Alimentary canal of the same.

4. Details of the same.

$\mathrm{A}=$ longitudinal section of mesenteron and cesophagus.

$B=$ transverse section of same, through line $a-b$

$\mathrm{C}=$ longitudinal sections of ceaca of reservoir.

4a:

$\mathrm{D}=$ longitudinal section of mesenteron and œsophagus of Perkinsiella saccharicida.

$\mathrm{E}=$ transverse section of same, through line $\mathrm{a}-\mathrm{b}$.

5. Transverse section of young stem of plant, showing setæ of a mealybug amongst tissues.

6. Alimentary canal of Oliarus sp. Fam. Cixiidæ.

7. Alimentary canal of Dictyophorodelphax mirabilis Sw., Fam. Delphacidæ.

8. Alimentary canal of Perkinsiella saccharicida Kirk., Fam. Delphacidæ.

9. Alimentary canal of Tricentrus albomaculatus Dist., Fam. Membracidæ.

10. Alimentary canal of Aleyrodes sonchi Kot., Fam. Aleyrodidæ.

In all the figures of the alimentary canal the parts are more or less opened out, so as to show clearly.

\section{LETTERING OF FIGURES.}

$\mathbf{a}=$ anus.

abd $=$ abdomen.

$\mathrm{bm}=$ basement-membrane.

$\mathrm{br}=$ brain .

$\mathrm{ca}=$ cæcum.

chi $=$ chitinous intima.

cs $=$ cardiac septum.

$\mathrm{cu}=$ cuticle.

$\mathrm{dm}^{1}=$ inner diagonal muscles of œsophagus.

$\mathrm{dm}^{2}=$ outer diagonal muscles of œsophagus.

en $=$ viscid fluid between epithelium and peritrophic membrane, probably containing the enzymes; only shown in the figures in two or three places, to keep them clear; except in figure 4a. ep=epithelium.

$\mathrm{fr}=$ food-reservoir.

$\mathrm{frm}=$ food-reservoir muscles.

$\mathrm{frv}=$ food-reservoir valve.

$\mathrm{g}=$ genital opening.

hd = head.

$\mathrm{hi}=$ hind intestine.

ht $=$ heart.

lab=labium.

$\operatorname{lm}=$ longitudinal muscles.

lœelumen of œesophagus.

$\mathrm{m}=$ muscles.

mes $=$ mesothorax .

met $=$ metathorax .

$\mathrm{mi}=$ mid-intestine (midgut, mesenteron).

$\mathrm{mp}=$ malpighian tubes. 
$\mathrm{n}=$ nucleus.

nc $=$ nerve-cord.

ns $=$ neural septum.

$œ=$ œesophagus.

$œ v=$ esophageal valve.

pe $=$ peritoneal membrane.

ph $=$ pharynx.

pm= peritrophic membrane.

$\mathrm{pp}=$ pharyngeal pump.

pro $=$ prothorax.

$\mathbf{R}$, rec $=$ rectum. $\mathrm{s}=$ setæ.

$\mathrm{sg}=$ salivary glands.

sgd = salivary gland duct.

sœ= subœsophageal ganglion .

$\mathrm{tg}=$ thoracic ganglion.

$\mathrm{tm}=$ transverse muscles.

$\operatorname{tr}=$ trachea .

$\mathrm{vm}=$ valve muscles.

$\mathrm{y}=$ yolk.

$1,2,3=$ coxæ.

\section{ON THE EARLY STAGES OF SOME WESTERN CATOCALA SPECIES.}

\section{By Wm. Barnes M. D. and J. MeDunnough Ph. D.}

Decatur, Ill.

It was our good fortune in the autumn of 1912 to obtain ova of several species of Catocala whose early stages had never been studied. Most of these we successfully bred through to the adult stage; colored figures of the larvæ have been made and will be published later in connection with Beutenmüller's Monograph of the Genus Catocala, which we have been asked by the trustees of the American Museum to revise and complete for publication; in the meantime we offer the following notes on the larval stages. The species in question may be roughly divided into two groupsthe oak feeders, comprising zoe, aholibah, ophelia, beutenmuelleri, and desdemona, and the willow and poplar feeders consisting of faustina, californica, irene, pura, and the species going under the name of aspasia Strecker. These two groups may be readily separated in the first larval stage by the fact that the setæ arising from the primary tubercles are much longer in the oak feeders than in the willow and poplar feeders, giving the former under a lense quite a spiny appearance, whereas the latter appear almost smooth. Among themselves the larvæ of each group are very similar in the first stage; the oak feeders are of a bluish-gray color with more or less strongly developed deep brown lateral blotches on the first four abdominal segments, 5-6 brown lateral lines and at times a similar centro-dorsal line; the presence of this dorsal 

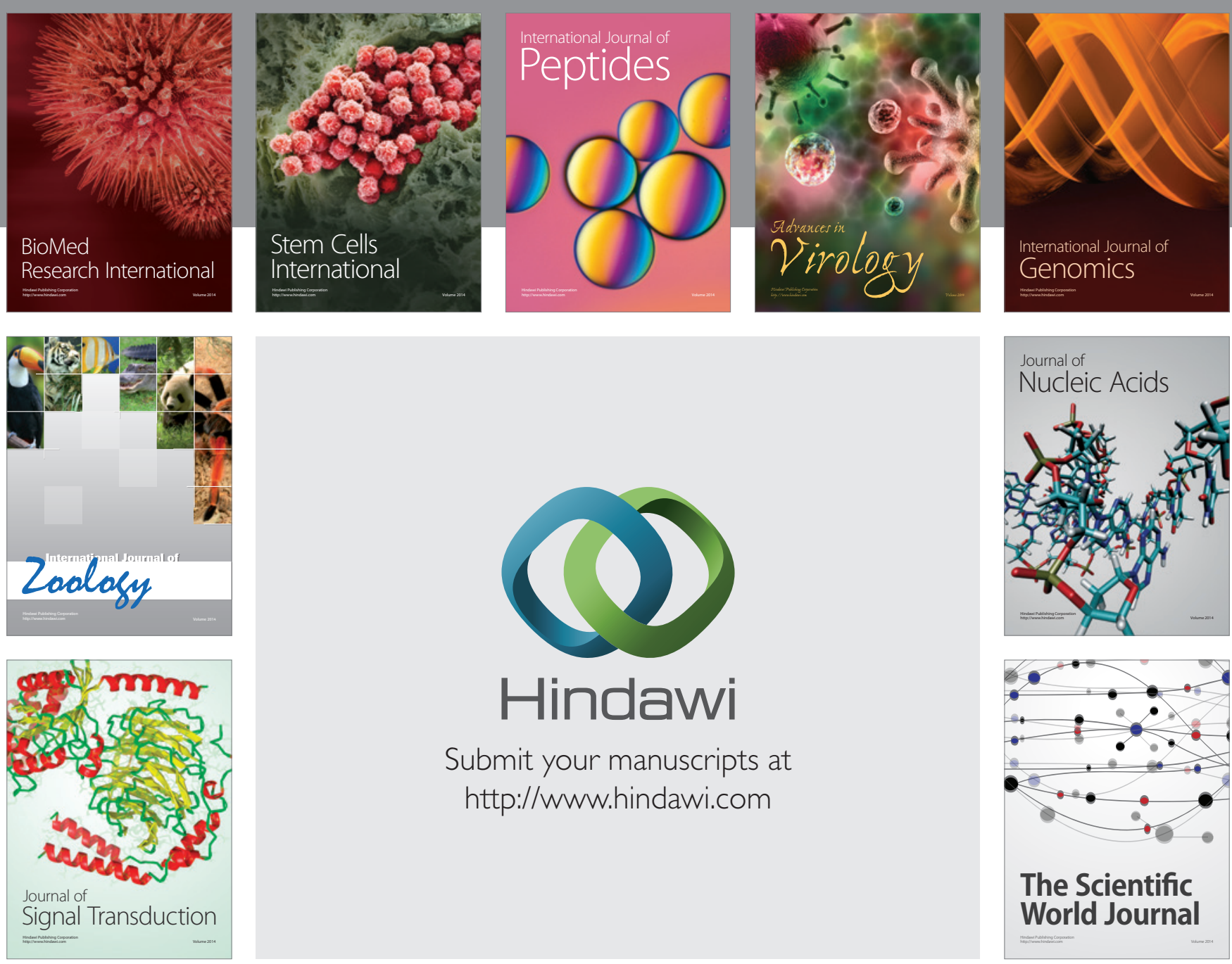

Submit your manuscripts at

http://www.hindawi.com
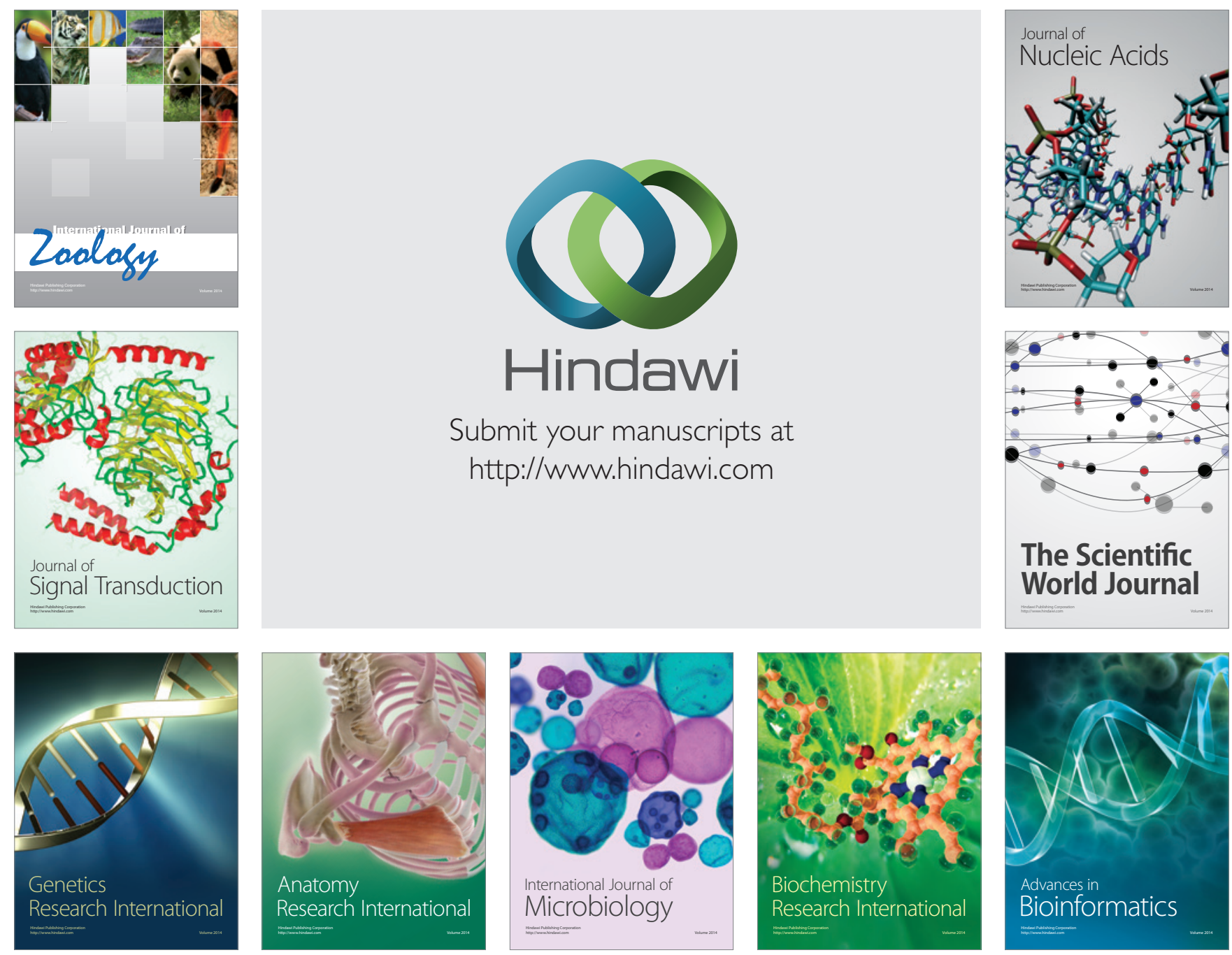

The Scientific World Journal
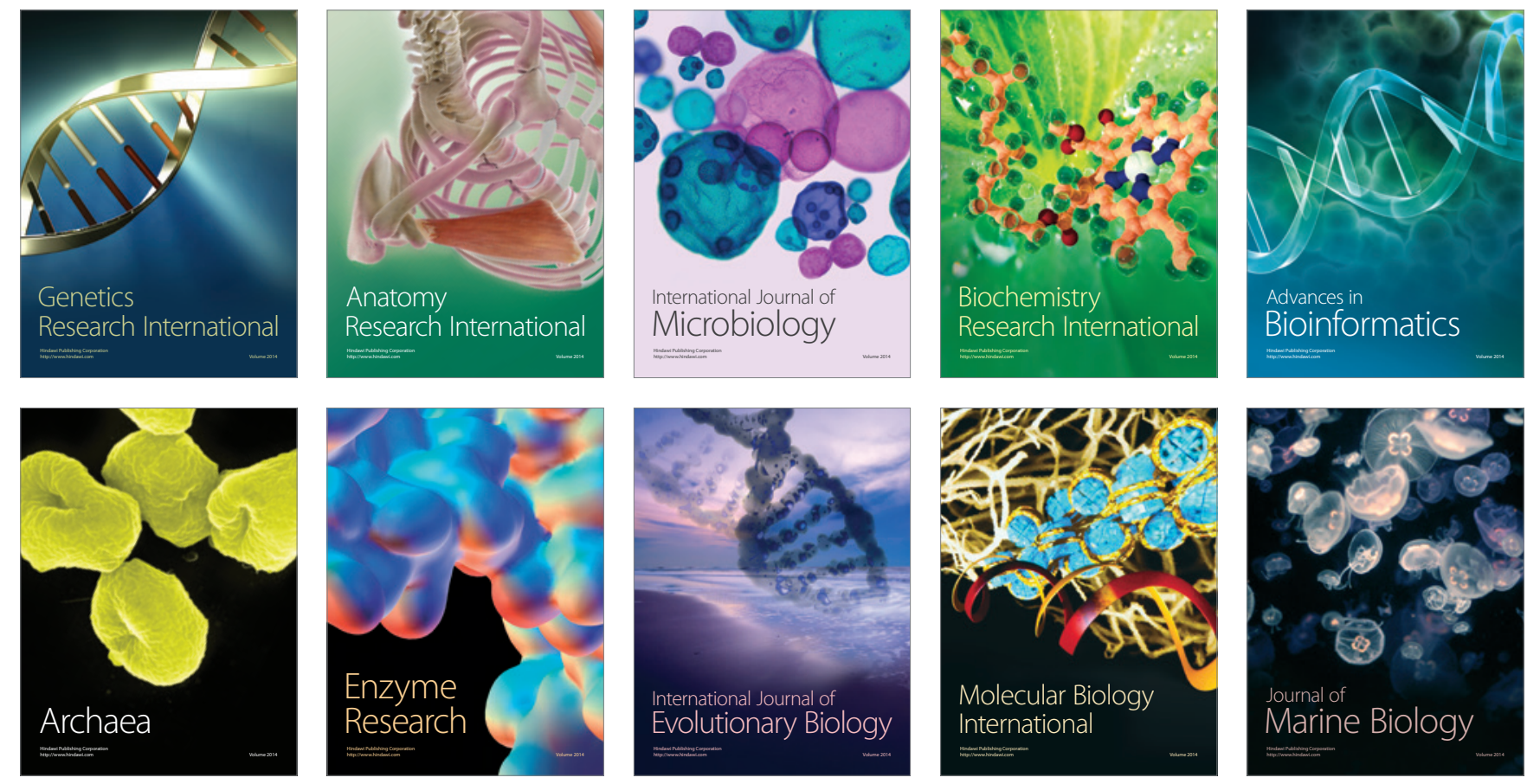